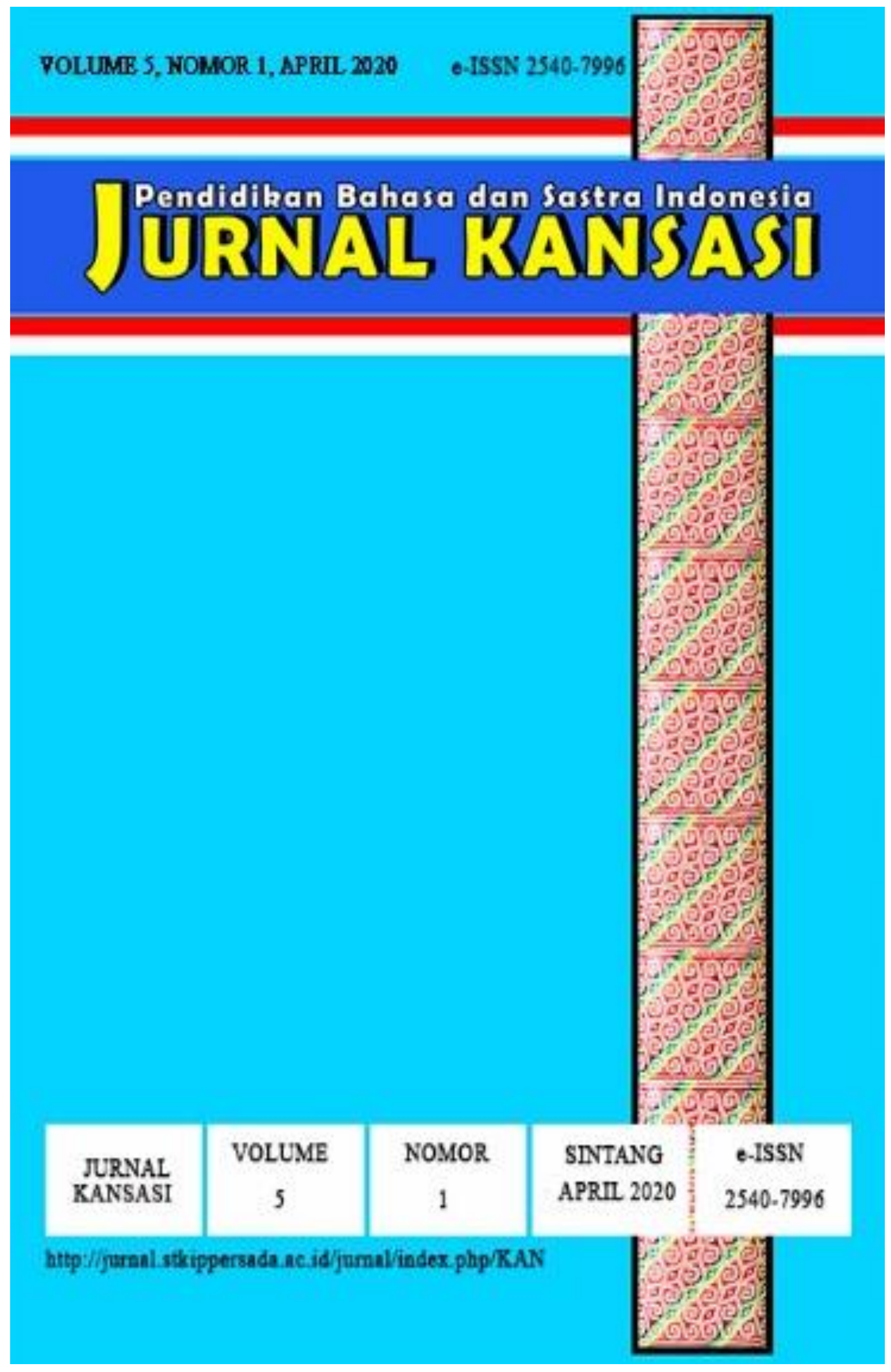




\section{JURNAL KANSASI \\ Volume 5, Nomor 1, April 2020}

Jurnal online pendidikan bahasa dan sastra Indonesia terbit dua kali setahun yaitu pada bulan April dan Oktober. Berisi tulisan yang diangkat dari hasil telaah dan penelitian di bidang pendidikan, bahasa, dan sastra Indonesia.

\section{Editor In Chief}

Debora Korining Tyas

\section{Deputy Chief Editor}

Sri Astuti

\section{Editor}

Tedi Suryadi

Ursula Dwi Oktaviani

Yudita Susanti

Muhammad Thamimi

Muchammad Djarot

\section{Reviewer}

Yusuf Olang

Herpanus

Bani Sudardi

Yoseph Yapi Taum

Agus Wartiningsih

\section{Administratative Staffs \\ Valentinus Ola Beding \\ Evi Fitrianingrum}

Alamat Redkasi: Program Studi Pendidikan Bahasa dan Sastra Indonesia STKIP Persada Khatulistiwa Sintang, Jl. Pertamina Sengkuang, Kotak Pos 126, Hp/WA. 082150544710.

Website e-journal KANSASI: http://jurnal.stkippersada.ac.id/jurnal/index.php/KAN

Jurnal ilmiah online KASASI diterbitkan oleh Program Studi Pendidikan Bahasa dan Sastra Indonesia STKIP Persada Khatulistiwa Sintang. Terbit sejak April 2016.

Penyunting menerima tulisan ilmiah yang belum pernah diterbitkan dimedia lain, baik cetak maupun elektronik. Naskah diketik untuk ukuran HVS A4 dengan spasi satu koma lima, maksimal 20 halaman. Tulisan yang masuk direview dan selanjutnya untuk diterbitkan. 


\section{JURNAL KANSASI \\ Volume 5, Nomor 1, April 2020}

\section{DAFTAR ISI}

Halaman

Hubungan Kemandirian Belajar Terhadap Hasil Belajar Siswa pada Mata Pelajaran Bahasa Indonesia Kelas VIII $1-8$

SMP N 02 Tempunak

\section{Herpanus, Evi Fitria Ningrum, Ahensius Bantut}

STKIP Persada Khatulistiwa Sintang

Analisis Kesulitan Membaca Permulaan pada Sub Tema Tugasku

Sebagai Umat Beragama pada Siswa Kelas II SD Negeri 06

Setapang Laut Ketungau Hilir

Ursula Dwi Oktaviani, Gabriel Serani, Etikustini

STKIP Persada Khatulistiwa Sintang

Analisis Struktural Kumpulan Cerita Rakyat

Dayak Jangkang Tanjung

Valentinus Ola Beding, Tedi Suaryadi, Frideta Heni

STKIP Persada Khatulistiwa Sintang

Peningkatan Keterampilan Menulis Karangan Deskripsi

Menggunakan Media Miniatur (Maket)

Debora Korining Tyas, Sudarto, Ahmad Ridho Inoviar

STKIP Persada Khatulistiwa Sintang

Hubungan Kebiasaan Menulis dengan Kemampuan Menulis Cerpen pada Siswa Kelas XI Sekolah Menengah Atas

Nusantara Indah Sintang

Yusuf Olang, Evi Fitrianingrum, Markulanus Alex

$55-63$

STKIP Persada Khatulistiwa Sintang

Peningkatan Hasil Belajar Siswa Menggunakan

Metode Talking Stick pada Pembelajaran Tematik

Tedi Suryadi, Meranti Sintauli Tampubolon

$64-70$

STKIP Persada Khatulistiwa Sintang

Peningkatan Penguasaan Kosakata Bahasa Indonesia

Menggunakan Media Gambar pada Siswa Kelas 1

Sekolah Dasar Negeri 43 Tapang Aceh Tahun Ajaran 2019/2020

$71-80$

Gabriel Serani, Ilinawati, Lidia Heni

STKIP Persada Khatulistiwa Sintang 
Hubungan Hasil Belajar Siswa Dengan Kemampuan

Menerapkan Nilai-Nilai Pancasila

Agnesia Hartini, Lukas Robinson

$81-91$

STKIP Persada Khatulistiwa Sintang

Proses Dan Makna Simbol Ritual Munjong Dayak Tobag

Yudita Susanti, Yusuf Olang, Marselina Risca

$92-98$

STKIP Persada Khatulistiwa Sintang

Penerapan Pendekatan Eksploratory Discovery untuk Meningkatkan

Motivasi dan Hasil Belajar Kognitif

Sirilus Sirhi, Hendrikus Julung, Valentina Suci Susanti

$99-112$

STKIP Persada Khatulistiwa Sintang

Analisis Makna Bahasa Promosi Katalog Oriflame

Edisi Bulan Januari-Maret Tahun 2019

$113-126$

Ursula Dwi Oktaviani, Debora Korining Tyas, Ira Winarti

STKIP Persada Khatulistiwa Sintang

Peran Guru Pkn dalam Membina Civic Skill Siswa

Sekolah Menengah Pertama Negeri 7

Agnesia Hartini, Simon Petrus

$127-137$

STKIP Persada Khatulistiwa Sintang 
Vol. 5, No. 1, April 2020

e-ISSN: 2540-7996

http://jurnal.stkippersada.ac.id/jurnal/index.php/KAN/index

\title{
PENINGKATAN PENGUASAAN KOSAKATA BAHASA INDONESIA MENGGUNAKAN MEDIA GAMBAR PADA SISWA KELAS 1 SEKOLAH DASAR NEGERI 43 TAPANG ACEH TAHUN AJARAN 2019/2020
}

\author{
Gabriel Serani $^{1}$, Ilinawati² ${ }^{2}$ Lidia Heni $^{3}$ \\ ${ }^{1}$ STKIP Persada Khatulistiwa, ${ }^{2}$ STKIP Persada Khatulistiwa, \\ ${ }^{3}$ STKIP Persada Khatulistiwa, \\ e-mail: ebietatw@gmail.com ${ }^{1}$, ilina_selvin@yahoo.com ${ }^{2}$, lidiaheni00@gmail.com ${ }^{3}$ \\ Diajukan, 8 Februari 2020, Diterima, 6 Maret 2020, Dterbitkan, 1 April 2020
}

\begin{abstract}
ABSTRAK
Tujuan utama penelitian ini adalah untuk mendeskripsikan peningkatan penguasaan kosakata bahasa Indonesia menggunakan media gambar pada siswa kelas 1 sekolah dasar negeri 43 Tapang Aceh tahun ajaran 2019/2020. Penelitian ini terdiri dari dua variabel, yaitu penguasaan kosakata bahasa Indonesia pada materi kegiatan pagi hari dan media gambar. Metode penelitian menggunakan metode deskriptif kualitatif, dengan bentuk penelitian menggunakan penelitian tindakan kelas. Subjek penelitian adalah siswa kelas 1 yang berjumlah 15 siswa. Teknik pengumpulan data yang digunakan adalah teknik observasi dan teknik pengukuran, sedangkan alat pengumpulan data menggunakan lembar observasi, lembar catatan lapangan dan lembar tes. Hasil observasi menunjukan aktivitas guru mendapat kategori sangat baik dengan persentase $93,75 \%$ pada siklus II, dan partisipasi siswa mendapat kategori sangat baik dengan persentase $94,44 \%$ pada siklus II. Hasil penelitian ini menunjukan adanya peningkatan penguasaan kosakata bahasa Indonesia menggunakan media gambar. Hal ini dibuktikan dengan adanya peningkatan rata-rata penguasaan kosakata siswa pada pra siklus sebesar 13\%, meningkat menjadi 73,33\% pada tindakan siklus I, dan mencapai 93,33\% pada tindakan siklus II.
\end{abstract}

\section{Kata Kunci: Penguasaan Kosakata, Media Gambar}

\section{ABSTRACT}

The main objective of this research was to describe theimproving of Indonesian vocabulary mastery by using media gambar to the First Grade Students of SDN 43 Tapang Aceh, Academic Year 2019/2020. There were two variables in this reserach, they were, mastery of Indonesian vocabulary the applying of Media Gambar. The research method used was descriptive qualitative method, and classroom action research as the form of the research. The research subjects were first grade students which amounted to 15 students. Data collection techniques used were observation and measurement techniques, while the data collection tools used were observation sheets, field notes and test. The observation results showed that the teacher's activity was very good with a percentage of $93.75 \%$ in the second cycle, and student participation was very good with a percentage of $94.44 \%$ in the second cycle. The results of this research indicated an increase in mastery of Indonesian vocabulary by using 
Vol. 5, No. 1, April 2020

e-ISSN: 2540-7996

http://jurnal.stkippersada.ac.id/jurnal/index.php/KAN/index

Media Gambar. This was evidenced by an increase in the students' average vocabulary score at the pre cycle was $13 \%$, increased to $73.33 \%$ in the first cycle, and reached $93.33 \%$ in the second cycle.

Kata kunci: Vocabulary Mastery, Media Gambar

\section{PENDAHULUAN (Times New Roman, 12, Spasi 1.5, Justify, Bold)}

Bahasa tidak dapat dipisahkan dari kehidupan manusia, sebab sebagai makhluk sosial bahasa digunakan untuk berkomunikasi dengan makhluk hidup lainnya. Manusia tidak dapat hidup tanpa makhluk hidup lainnya. Bahasa sebagai penyatu interaksi manusia dalam bentuk komunikasi (Pramesti 2015:83).

Di Indonesia, bahasa Indonesiamenjadi salah satu mata pelajaran yangwajib diajarkan pada pendidikan formal,sejak tingkat sekolah dasar sampai tingkat perguruan tinggi. Dalam proses pembelajarannya, materi bahasa Indonesia diberikan sesuai dengan kebutuhan siswa.

Ruang lingkup bahasa Indonesia di sekolah dasar dalam kurikulum 2013 yang sudah terintregasi dengan mata pelajaran lainnya melalui kompetensi dasar adalah menggunakan bahasa secara efektif dan efisien sesuai dengan etika yang berlaku, baik secara lisan maupun tulisan, menghargai dan bangga menggunakan bahasa Indonesia dengan tepat dan kreatif untuk berbagai tujuan. Salah satu pembelajaran bahasa Indonesia adalah pembelajaran kosakata. perlu disadari bahwa belajar bahasa Indonesia tidak akan terlepas dari belajar kosakata. Nastiti (2017:5) menyatakan bahwa penguasaaan kosakata adalah kegiatan menguasai atau kemampuan memahami dan menggunakan kata-kata yang terdapat dalam suatu bahasa, baik lisan maupun tulisan.

Menurut Tarigan dalamWidiyaningsih (2017::3) yang menyatakan bahwa kualitas berbahasa seseorang jelas bergantung pada kualitas dan kuantitas kosakata yang dimilikinya, maka semakin banyak kosakata yang dimilikinya maka semakin baik pula keterampilannya dalam berbahasa. Kosakata sebagai salah satu materi pelajaran bahasa Indonesia di sekolah mempunyai peran penting sabagai dasar siswa untuk menguasai materi pembelajaran baik pembelajaran bahasa Indonesia maupun pembelajaran lainnya yang menyebabkan pembelajarankosakata semakin harus dipelajari secara lebih serius dan terarah.

Berdasarkan hasil tes pra observasi yang dilakukan peneliti bersama dengan guru kelas 1 di kelas 1SDN NO. 43 Tapang Aceh pada tanggal 12 maret 2019, bahwa penguasaan kosakata bahasa Indonesia di sekolah belum sepenuhnya berhasil dan belum mencapai hasil yang diharapkan yaitu dengan kriteria ketuntasan minimal 70. Dari 15 siswa hanya 2 siswa yang mampu menyebutkan 7-8 kata tentang kegiatan pagi hari secara benar, 10 siswa hanya mampu menyebutkan 4-6 kata tentang kediatan pagi hari namun itupun masih menyebutkan secara terbata-bata, dan 3 siswa hanya mampu menyebutkan 1-3 kata tentang kegiatan pagi hari dibantu oleh gurunya. Hal tersebut menunjukan masih rendahnya penguasaan kosakata bahasa Indonesia pada siswa. 
Vol. 5, No. 1, April 2020

e-ISSN: 2540-7996

http://jurnal.stkippersada.ac.id/jurnal/index.php/KAN/index

Kendala penyebab rendahnya penguasaan kosakata bahasa Indonesia pada siswa kelas 1 SDN

NO. 43 Tapang Aceh karena siswa kurang aktif dalam penggunaan bahasa Indonesia sebagai alat komunikasi pada kehidupan seharihari, pada umumnya siswa pada sekolah dasar tersebut hanya menggunakan bahasa Indonesia pada saat jam pelajaran berlangsung saja dan dalam kehidupan sehari-hari mereka pada umumnya masih menggunakan bahasa daerah setempat yaitu bahasa daerah setempat yaitu bahasa Dayak Seberuang. Selain itu, kendala yang muncul pada proses pembelajaran disebabkan karena media yang digunakan dalam pembelajaran masih terbatas, dan belum bervariasi sehingga menyebabkan siswa cepat bosan dan kurang aktif terhadap pembelajaran, dan pada hasilnya, siswa bahkan sibuk sendiri bersama temantemannya tanpa memperhatikan penjelasan gurunya. Sehingga terjadi masalah dalam proses pembelajaran menjadi tidak maksimal.

Dalam pelaksanaan tindakan yang dilakukan akan berkolaborasi dengan guru kelas 1 pada sekolah tersebut dengan menggunakan media gambar. Menurut Angkowo dan Kosasih (2007:26) menyatakan bahwa "media gambar adalah penyajian visual dua dimensi yang memanfaatkan rancangan gambar sebagai sarana pertimbangan mengenai kehidupan sehari-hari”. Media gambar dipilih sebab fungsi dari media gambar menurut Angkowo dan Kosasih (2007:27), "fungsi media gambar adalah sebagai alat bantu pembelajaran, yang ikut mempengaruhi situasi, kondisi dan lingkungan belajar dalam rangka mencapai tujuan pembelajaran yang telah diciptakan dan didesain oleh guru".

Nastiti (2017:5) menyatakan bahwa penguasaaan kosakata adalah kegiatan menguasai atau kemampuan memahami makna dan menggunakan kata-kata dalam bahasa Indonesia, baik lisan maupun tulisan. Watts dalam Khomsah (2011:21) memperkirakan jumlah kosakata yang dikuasai seseorang penutur bahasa yaitu (1) umur 5 tahun menguasai 2000 kata; (2) umur 7 tahun menguasai 7000 kata; (3) umur 14 tahun menguasai 14.000 kata; (4) umur 17 tahun menguasai 150.000 kata; dan (5) umur 19 tahun menguasai 600.000 kata. Berbeda dengan Dardjowidjojo dalam Khomsah (2011: 24) yang tidak menjelaskan jumlah kosakata yang dimiliki penutur bahasa tetapi lebih jauh membahas pemerolehan kosakata. Istilah pemerolehan digunakan sebagai padanan, yaitu proses penguasaan bahasa yang dilakukan anak-anak secara natural pada waktu ia belajar bahasa ibunya. Istilah pemerolehan bahasa tidak hanya digunakan untuk memperoleh bahasa kedua. Pemerolehan bahasa adalah bagian yang tidak terpisah dari perkembangan kognitif secara keseluruhan, dengan kata lain bahasa adalah hasil dari perkembangan intelek secara keseluruhan dan sebagai lanjutan pola-pola perilaku yang sederhana. Penguasaan kosakata merupakan kemampuan seseorang dalam menguasai atau kemampuan memahami makna serta menggunakan kata-kata yang terdapat dalam bahasa Indonesia baik lisan maupun tulisan.

Berdasarkan uraian tersebut maka peneliti perlu melakukan penelitian tindakan kelas dengan judul "Peningkatan Penguasaan Kosakata Bahasa Indonesia Menggunakan Media Gambar pada Siswa Kelas 1 SDN NO. 43 Tapang Aceh Tahun Ajaran 2019/2020”. 
Vol. 5, No. 1, April 2020

e-ISSN: 2540-7996

http://jurnal.stkippersada.ac.id/jurnal/index.php/KAN/index

\section{METODE PENELITIAN}

Pendekatan yang digunakan dalam penelitian ini adalah pendekatan kualitatif dengan menggunakan metode deskriptif dan bentuk penelitian tindakan kelas. Wardhani dan Kuswaya Wihardit (2008:1.4) mendefinisikan bahwa "Penelitian tindakan kelas adalah penelitian yang dilakukan oleh guru didalam kelasnya sendiri melalui refleksi diri, dengan tujuan untuk memperbaiki kinerja sebagai guru, sehingga hasil belajar siswa menjadi meningkat". Lokasi penelitian dilaksanakan di Sekolah Dasar Negeri 43 Tapang Aceh Kecamatan Sepauk Kabupaten Sintang dengan subjek penelitian adalah kelas 1 Sekolah Dasar Negeri 43 Tapang Aceh tahun ajaran 2019/2020. Penelitian ini dilaksanakan dalam dua siklus. Dalam penelitian ini, peneliti melibatkan seorang guru kelas 1 untuk menjadi kolaborator.

Sumber data dalam penelitian ini adalah data primer dan data sekunder. Teknik pengumpulan data yang digunakan adalah teknik observasi dan teknik pengukuran dengan alat pengumpulan data yang digunakan adalah lembar observasi, catatan lapangan dan tes. Teknik analisis data yang digunakan dalam penelitian menggunakan teknik analisis model Miles dan Huberman. Adapun tahapan dalam analisis data terdiri dari tahap pengumpulan data, tahap reduksi data, tahap display data dan tahap verifikasi atau kesimpulan.

\section{PEMBAHASAN}

\section{a. Hasil Penelitian}

Berdasarkan analisis data yang diperoleh dalam penelitian ini, maka dapat dijelaskan hasil penelitian adalah sebagai berikut :

1. Penggunaan media gambar meningkatkan penguasaan kosakata bahasa Indonesia pada materi kegiatan pagi hari pada siswa kelas 1 SD Negeri 43 Tapang Aceh tahun ajaran 2019/2020.

Berdasarkan hasil observasi yang dilakukan oleh kolaborator terhadap penelitian dengan menggunakan lembar observasi aktivitas guru pada siklus I dan siklus II, maka pada siklus II dapat disimpulkan bahwa aktivitas guru dalam melaksanakan pembelajaran dengan menggunakan media gambar sudah berjalan dengan baik, guru sudah bisa membawa siswa kedalam pembelajaran yang menyenangkan dan membuat siswa lebih terlibat aktif dalam SIMPULAN (Times New Roman, 12, Spasi 1.5, Justify, Bold) Berisikan kesimpulan dari pembahasan mengacu pada tujuan penelitian. Setiap proses pembelajaran baik dalam melakukan diskusi atau tanya jawab maupun dalam mengerjakan tugas yang diberikan oleh guru dan sesuai dengan tujuan yaitu untuk meningkatkan penguasaan kosakata bahasa Indonesia siswa. Terbukti dari hasil obsevasi aktivitas guru pada siklus II sebesar 94\% dengan kategori "sangat 
Vol. 5, No. 1, April 2020

e-ISSN: 2540-7996

http://jurnal.stkippersada.ac.id/jurnal/index.php/KAN/index

baik". Dan siswa juga sudah terlihat aktif dalam berdiskusi maupun tanya jawab, dan siswa merasa tertarik dengan media yang digunakan oleh guru.

Berikut grafik perbandingan siklus I dan siklus II

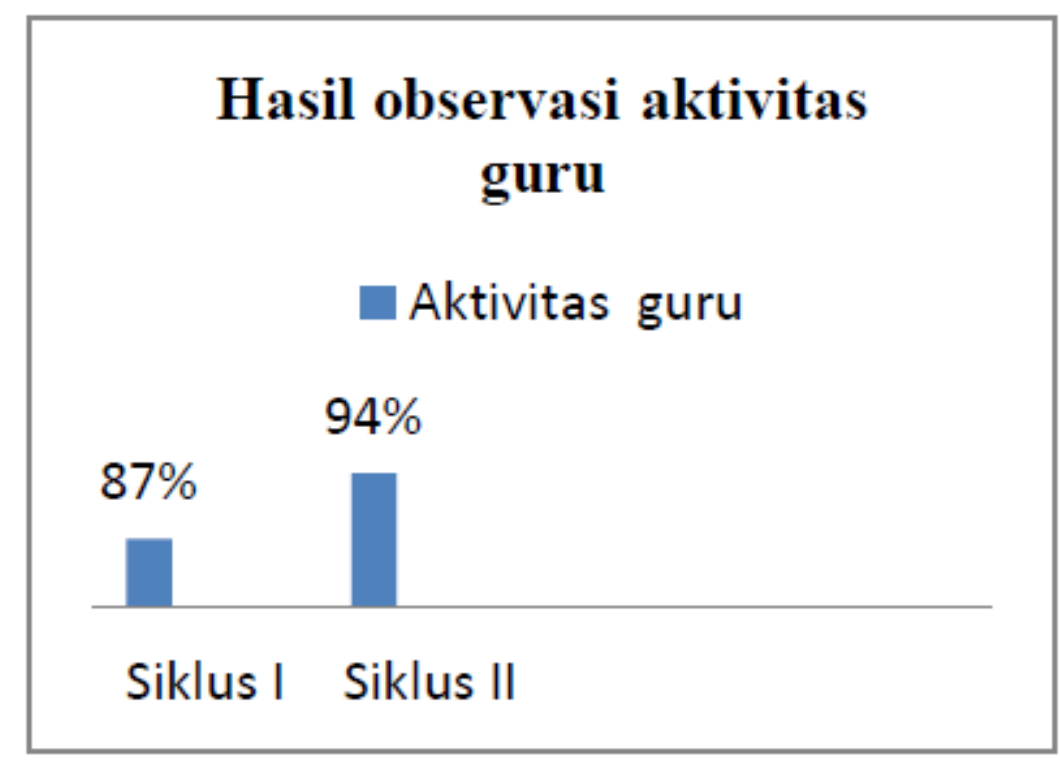

2. Peningkatan pengguasaan kosakata bahasa Indonesia menggunakan media gambar pada siswa kelas 1 SD Negeri 43 Tapang Aceh tahun ajaran 2019/2020 sudah dikategorikan sangat baik.

Berdasarkan hasil tes yang diberikan oleh guru yang telah dianalisis pada siklus II mengalami peningkatan yang signifikan menjadi 93,33\%, hal tersebut dapat dilihat dari 15 siswa, 14 siswa sudah bisa mencapai KKM sedangkan 1 siswa belum mampu mencapai indikator.

Berikut disajikan grafik perbandingan hasil tes penguasaan kosakata bahasa Indonesia dari prasiklus, siklus I dan siklus II. 
Vol. 5, No. 1, April 2020

e-ISSN: 2540-7996

http://jurnal.stkippersada.ac.id/jurnal/index.php/KAN/index

\section{ketuntasan klasikal}

u Jumlah siswa tuntas

11

14

\section{Siklus I Siklus II}

3. Partisipasi siswa terhadap penggunaan media gambar untuk meningkatkan penguasaan kosakata bahasa Indonesia pada siswa kelas 1 SD Negeri 43 Tapang Aceh tahun ajaran 2019/2020.

Berdasarkan hasil observasi partisipasi siswa terhadap penggunaan media gambar pada siklus II pada meteri kegiatan pagi hari, sudah terjadi peningkatan dari siklus I ke siklus II, dimana pada siklus II diperoleh 88\% dengan kategori "sangat baik". Siswa sudah melakukan sebagian besar kegiatan pembelajaran dengan sangat baik dalam merespons semua kegiatan yang diperintah oleh guru.

Berikut grafik perbandingan siklus I dan siklus II :

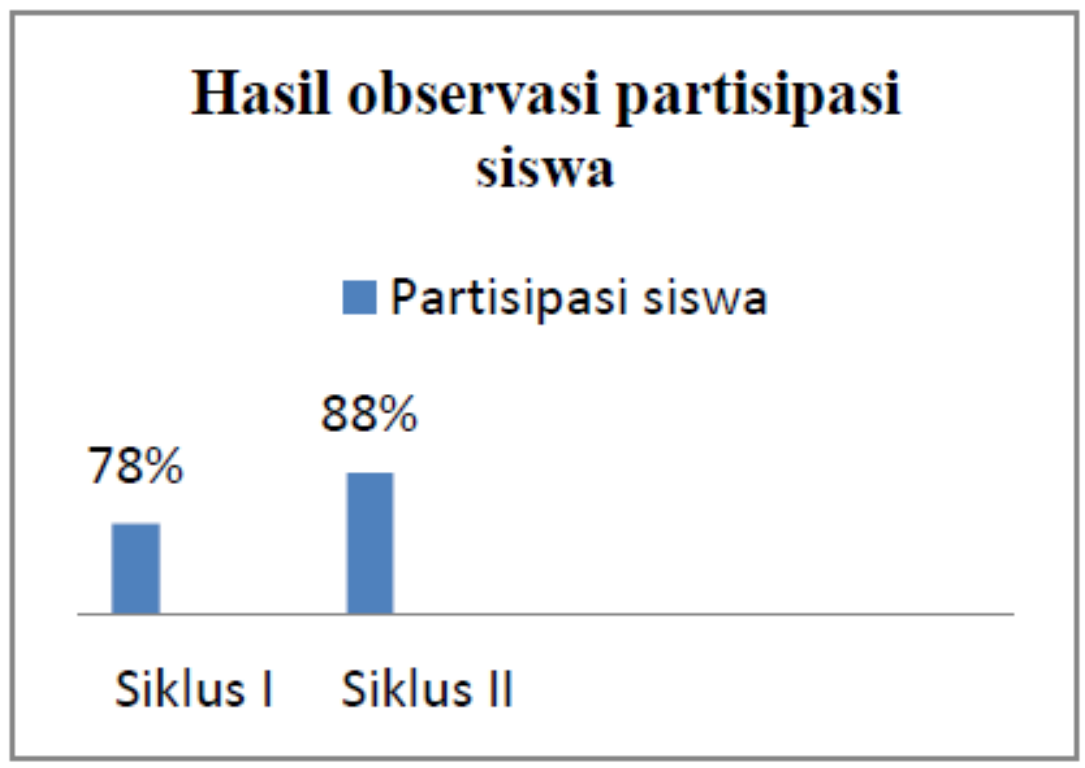

Berikut hasil catatan lapangan siklus II pada penelitian ini: 
Vol. 5, No. 1, April 2020

e-ISSN: 2540-7996

http://jurnal.stkippersada.ac.id/jurnal/index.php/KAN/index

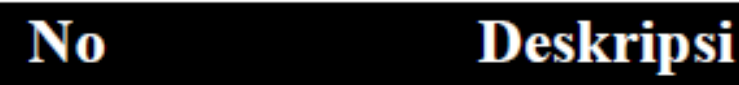

1 Guru tidak memberikan

kesempatan kepada siswa untuk mengeluarkan pendapat karena

terlalu asik dalam menyampaikan materi dan melakukan permainan

bersama siswa

2 Guru sudah dapat menguasai

kelas dengan baik

3 Siswa belum terdengar bertanya

tentang materi yang disampaikan

guru

4 Siswa terdengar ribut saat mengerjakan tugas yang

\section{diberikan oleh guru}

b. Pembahasan Hasil Penelitian

Adapun pembahasan hasil penelitian adalah sebagai berikut :

1) Penggunaan Media Gambar dalam meningkatkan Penguasaan kosakata bahasa Indonesia. Berdasarkan grafik perbandingan hasil observasi aktivitas guru siklus I dan siklus II tersebut, dapat disimpulkan bahwa pada siklus II guru sudah melakukan kegiatan pembelajaran dangan sangat baik dengan persentase keseluruhan sebesar $94 \%$, terjadi peningkatan sebesar 7\% dari siklus I sebesar $87 \%$ menjadi $94 \%$ pada siklus II berdasarkan persentase diatas sudah terjadi peningkatan terhadap aktivitas guru terhadap penggunaan media gambar dan sudah mencapai indikator keberhasilan yang ditargetkan sehingga tidak perlu lagi dilakukan tindakan pada siklus selanjutnya. 
Vol. 5, No. 1, April 2020

e-ISSN: 2540-7996

http://jurnal.stkippersada.ac.id/jurnal/index.php/KAN/index

Hasil penelitian ini diperkuat oleh hasil kajian yang relevan menurut Widiyaningsih (2017), pembelajaran dengan menggunakan media gambar mampu menarik perhatian siswa sehingga

2) Peningkatan pengguasaan kosakata bahasa Indonesia menggunakan media gambar pada siswa kelas 1 SD Negeri 43 Tapang Aceh tahun ajaran 2019/2020.

Berdasarkan grafik perbandingan ketuntasan klasikal pada siklus I dan siklus II, terjadi peningkatan penguasaan kosakata bahasa Indonesia pada siklus II ada 14 siswa yang tuntas dari siklus I hanya 11 siswa. Adapun hasil tes pada siklus II pada kriteria menyebutkan kosakata bahasa Indonesia tentang kegiatan pagi hari adalah dari 15 siswa sudah 12 siswa mampu menyebutkan lebih dari 10 kosakata bahasa Indonesia tentang kegiatan pagi hari, dan 1 siswa sudah mampu menyebutkan 7-10 kosakata bahasa Indonesia tentang kegiatan pagi hari sedangkan 1 siswa lainnya mampu menyebutkan 4-6 kosakata bahasa Indonesia tentang kegiatan pagi hari. sedangkan pada kriteria menentukan gambar yaitu 13 siswa sudah mampu menentukan lebih dari 10 gambar tentang kegiatan pagi hari, 2 siswa sudah mmpu menentukan 7- 10 gambar tentang kegiatan pagi hari. kemudian pada kriteria melengkapi huruf diperoleh 9 siswa sudah mampu melengkapi lebih dari 10 huruf tentang kegiatan pagi hari,sedangkan 6 siswa lainnya sudah mampu melengkapi 7-10 huruf tentang kegiatan pagi hari, jadi dari hasil tersebut diperoleh nilai siswa, dimana pada siklus II dari 15 siswa hanya 1 siswa yang belum mencapai ketuntasan berarti 14 siswa sudah bisa mencapai target dengan ketuntasan klasikal sebesar 93,33\% berarti pada siklus II penelitian sudah mencapai indikator yang diharapkan yaitu $85-90 \%$ maka tidak dilanjutkan pada siklus berikutnya. Berarti, penelitian tindakan kelas yang dilakukan terhadap peningkatan penguasaan kosakata bahasa Indonesia menggunakan media gambar pada siswa kelas 1 SD 43 Tapang Aceh tahun ajaran 2019/2020 berhasil.

Penelitian ini diperkuat berdasarkan hasil kajian yang relevan menurut Perwasih (2013), media gambar dapat meningkatkan hasil belajar siswa pada pembelajaran tematik tema kegiatan sehari-hari dilihat dari hasil persenrase ketuntasan hasil belajar siswa dari siklus I ke siklus II yaitu 70\% pada siklus I menjadi 85\% pada siklus II.

3) Partisipasi siswa terhadap penggunaan media gambar untuk meningkatkan penguasaan kosakata bahasa Indonesia pada siswa kelas 1 SD Negeri 43 Tapang Aceh tahun ajaran 2019/2020.

Berdasarkan grafik perbandingan hasil observasi partisipasi siswa siklus I dan siklus II, dapat disimpulkan bahwa pada siklus II siswa sudah sangat berpartisipasi aktif dalam melakukan kegiatan pembelajaran dengan persentase sebesar $88 \%$ sehingga terjadi peningkatan $10 \%$ dari siklus I yaitu $78 \%$ dan meningkat menjadi $88 \%$ pada siklus II, 
Vol. 5, No. 1, April 2020

e-ISSN: 2540-7996

http://jurnal.stkippersada.ac.id/jurnal/index.php/KAN/index

sehingga berdasarkan persentase tersebut berarti sudah terjadi peingkatan terhadap partisipasi siswa pada saat mengikuti pembelajaran dengan menggunakan media gambar.

Hasil penelitian ini diperkuat berdasarkan hasil kajian yang relevan menurut Amelia (2017), partisipasi adalah cara penting untuk meningkatkan pembelajaran, membuat pengalaman kelas lebih efektif. Penelitian menunjukan bahwa ketika siswa berpartisipasi, mereka lebih termotivasi dan belaja lebih aktif.

\section{SIMPULAN}

Berdasarkan hasil dan analisis data dapat disimpulkan secara umum bahwa penggunaan media dapat meningkatkan penguasaan kosakata bahasa Indonesia pada siswa kelas 1 Sekolah Dasar Negeri 43 Tapang Aceh tahun ajaran 2019/2020. Hal ini dibuktikan berdasarkan hasil observasi, catatan lapangan dan hasil tes pra-siklus, siklus I dan siklus II bahwa sudah terjadi peningkatan, baik dalam proses pembelajaran yang dilakukan oleh guru, hasil penguasaan kosakata bahasa siswa maupun partisipasi atau keterlibatan siswa sudah sangat baik, siswa sudah sangat aktif dalam proses pembelajaran, guru dapat membuat siswa termotivasi dan terlibat aktif dalam proses pembelajaran dengan menggunakan media gambar sehingga tujuan pembelajaran dapat tercapai dan pembelajaran pun menjadi lebih menyenangkan.

\section{DAFTAR PUSTAKA}

Amelia. 2017. “Analisis Partisipasi Kelas Siswa Laki-laki dan Perempuan”. Jurnal Perempuan, Agama, dan Jender. Volume 16 nomor 01.

Ardian. 2017. "Upaya Peningkatan Penguasaan Kosakata Bahasa Indonesia pada Anak Kelompok TK B melalui Metode Bernyanyi di TK

Aisyiyah Demangan Sambi Boyolali tahun ajaran 2016/2017”. Skripsi. Surakarta : Institut Agama Islam Negeri Surakarta.

Arikunto. 2015. Penelitian Tindakan Kelas. Jakarta : Bumi Aksara.

Arikunto. 2013. Prosedur Penelitian Suatu Pendekatan Praktik. Jakarta : Rineka Cipta.

Angkowo, R. Dan A.Kosasih. 2007. Optimalisasi Media Pembelajaran. Jakarta : PT Grasido.

Febrisma, 2013. "Upaya Meningkatkan Kosakata Melalui Metode Bermain Peran Pada Anak

Tunagrahita Ringan Kelas D V di SLB Kartini Batam”. Jurnal Ilmiah Pendidikan Khusus.

Volume 01 nomor 02.

Handayani. 2013. "Meningkatkan Partisipasi Belajar Siswa dalam Pembelajaran IPS Menggunakan Metode Role Playing pada Siswa Kelas V SD Negeri Playen III.” Skripsi. Yogyakarta : Universitas Negeri Yogyakarta.

Heru. 2017. Aplikasi Penelitian Tindakan Kelas (PTK) dalam Pendidikan Kesehatan. Jawa Timur : Forum Ilmiah Kesehatan. 
Vol. 5, No. 1, April 2020

e-ISSN: 2540-7996

http://jurnal.stkippersada.ac.id/jurnal/index.php/KAN/index

Khomsah. 2011. "Peningkatan Penguasaan Kosakata melalui Media Pass Piture dengan Menggunakan Metode Permainan Kata pada Siswa Kelas B-2TK Kartika III-20 Srondol Semarang." Skripsi. Semarang : Universitas Negeri Semarang.

Moleong, 2016. Metodologi Penelitian Kualitatif. Bandung : PT Remaja Rosdakarya.

Murfiah. 2017. Pembelajaran Terpadu. Bandung : Refika Aditama

Nastiti, M. 2017. "Peningkatan Penguasaan Kosakata Melalui Metode Bursa Kata Siswa Kelas IVB SDN 01 Gunung

Sari Tahun Ajaran 2017/2018”. Skripsi. Mataram : Universitas Mataram.

Nurhayati. 2016. "Peningkatan Partisipasi dan Prestasi Belajar PKn dengan Model Pakem Siswa Sekolah Dasar. Jurnal Pendidikan Sekolah Dasar. Volume 02 nomor 01. Nurjannah. 2014. "Peningkatan Kemampuan Penguasaan Kosakata Melalui Kartu Huruf Bergambar Siswa Kelas II SDN 5 Soni”. Jurnal Kreatif Tadulako Online. Volume 04 nomor 08.

Perwasih, A. C. 2013. "Penerapan Media Gambar pada Tema Kegiatan Sehari-hari untuk Meningkatkan Hasil Belajar Siswa di Sekolah Dasar”. JPGSD. Volume 01 nomor 02.

Pramesti. 2015. "Peningkatan Penguasaan Kosakata Bahasa Indonesia dalam Keterampilan Membaca Melalui Teka Teki Silang”. Jurnal Puitika. Volume 11 nomor 01.

Rusilowati. 2017. Pengembangan Insrumen Penilaian. Semarang : Unnes Press.

Samsudin. 2016. “ Upaya Meningkatkan Hasil Belajar IPS melalui Media Gambar pada Siswa Kelas II MIN Melika Gunung Kidul”. Jurnal Pendidikan Madrasah. Volume 01 nomor 01.

Siregar. 2017. "Penggunaan Media Gambar untuk Meningkatkan Hasil Belajar IPA pada Siswa Sekolah Dasar”. Jurnal Ilmu Pendidikan Sosial, Sains, dan Humaniora. Volume 03 Nomor 04. Susanto, A. 2011. Perkembangan Anak Usia Dini Pengantar dalam Berbagai Aspeknya. Jakarta : Kencana Prenadamedia Group.

Sugiyono. 2015 . Metode Penelitian Kuantitatif, Kualitatif, dan R\&D. Bandung : Alfabeta

Sugiyono. 2018. Metode Penelitian Kuantitatif, Kualitatif, dan R \& D. Bandung : Alfabeta.

Tarigan. 2015. Pengajaran Kosakata. Bandung : CV Angkasa.

Widiyaningsih. 2017. "Peningkatan Penguasaan Kosakata melalui Penggunaan Media Gambar Seri pada Anak Kelompok B di TK Aba Miliran Muja Muju Umbulharjo, Yogyakarta”. Skripsi. Yogyakarta : Universitas Negeri Yogyakarta.

Wardani, I GAK dan Kuswaja Wihardit. 2008. Penelitian Tindakan Kelas. Jakarta: Universitas Terbuka 


\section{Petunjuk Bagi (Calon) Penulis Jurnal KANSASI}

1. Artikel yang ditulis untuk Jurnal KANSASI adalah hasil telaah dan hasil penelitian dibidang pendidikan, bahasa, dan sastra Indonesia serta tidak pernah diterbitkan dimedia lain, baik cetak maupun elektronik.

2. Naskah diketik dengan huruf Times New Romans, ukuran 12, dengan spasi 1,5, menggunakan kertas A4, margin atas, kiri, kanan dan bawah $2.54 \mathrm{~cm}$, dengan maksimum 20 halaman, dan diserahkan secara online melalui laman (http://jurnal.stkippersada.ac.id/jurnal/index.php/KAN) pada bagian submission, dan terlebih dahulu penulis melakukan registrasi sebagai penulis (author). Pada saat diserahkan, file dalam format $p d f$.

3. Nama penulis artikel dicantumkan tanpa gelar akademik dan di tempatkan di bawah judul artikel. Nama penulis hendaknya dilengkapi dengan alamat lembaga tempat penelitian serta alamat korespondensi. Bila naskah ditulis oleh tim, maka penyunting hanya berhubungan dengan penulis utama.

4. Artikel ditulis dalam bahasa Indonesia dengan format esai, disertakan judul masingmasing bagian artikel. Judul artikel dicetak dengan huruf kapital dengan posisi tengah atas dengan ukuran huruf 14 serta ditebalkan.

5. Sistematika artikel hasil telaah adalah: judul, nama penulis (tanpa gelar), identitas lembaga, alamat e-mail, abstrak (maksimum 250 kata), kata kunci, pendahuluan; pembahasan, simpulan, dan daftar pustaka.

6. Sistematika artikel hasil penelitian adalah: judul, nama penulis (tanpa gelar), abstrak (maksimum 250 kata), pendahuluan, metode penelitian, pembahasan, simpulan, dan daftar pustaka.

7. Sumber rujukan minmal terbitan sepuluh tahun terkahir. Rujukan yang diutamakan adalah sumber-sumber primer berupa laporan penelitian, atau artikel penelitian terbitan jurnal ilmiah.

8. Perujukan, pengutipan, tabel, dan gambar menggunakan ketentuan yang ada pada template penulisan artikel ilmiah pada Jurnal KANSASI.

9. Naskah diketik sesuai dengan tata bahasa baku bahasa Indonesia.

10. Setiap naskah ditelaah oleh penyunting ahli (reviewer) yang ditunjuk oleh penyunting sesuai dengan bidang kepakaran. Penulis artikel diberi kesempatan untuk merivisi naskah berdasrkan rekomendasi dari penyunting. Pemuatan atau penolakan naskah akan diberitahukan secara online melalui e-mail.

11. Penyuntingan naskah pra-terbit dikerjakan oleh penyunting (editor). Naskah pra-terbit dapat batal diterbitkan apabila diketahui bermasalah.

12. Segala sesuatu yang menyangkut perizinan atau penggunaan software computer untuk pembuatan naskah atau hal lain yang terkait dengan pelanggaran hak cipta yang dilakukan oleh penulis, serta konsekuensi hukum yang mungkin timbul karenanya, sepenuhnya menjadi tanggungjawab penulis. 